\title{
Assessing the Evolution of Human Settlements with 'Energy' as a Determinant
}

\author{
Manas Vijayan ${ }^{1, *}$, Akshay Patil ${ }^{l}$, and Vijay Kapse ${ }^{l}$ \\ ${ }^{1}$ Department of Architecture and Planning, VNIT Nagpur, Maharashtra, 440010, India
}

\begin{abstract}
Human settlements have evolved from caves in the Paleolithic Age to high rise buildings and cities in the modern era. Energy is one of the major driving forces in shaping the settlements of today. It is a fundamental of our everyday life and will continue to influence the future generations. It is also responsible for the many major looming threats faced by the world today, like climate change, ozone layer depletion, acid rains and global warming. Hence it is essential to investigate the influence of energy in shaping the settlements of the past, to understand the present, and to develop a vision for the future settlements. This paper is an attempt to study the evolution of human settlements based on the 'urban form determinants' framework developed by A.E.J. Morris with 'energy' as an additional determinant. The investigation proposes how energy has influenced in shaping the settlements of the past, and the correlation between energy and other urban form determinants. This study will help various stakeholders in developing an understanding on how energy can play a role in shaping a sustainable future, and also in identifying the parameters which influence them.
\end{abstract}

\section{Introduction}

We live in a period of time which is currently facing several megatrends that threat a sustainable development of the planet earth. These threats include depleting resources, deteriorating environment, climate change, pollution of air, water \& soil; most of which can be directly associated with the outcomes of various human activities. It goes without saying that the threats faced today cannot be seen in isolation but as a result of a series of events which happened in the past. It is hence essential to investigate the events in the past to understand the present, and to plan for the future.

Interestingly most of these threats can be directly related with energy consumed, and their associated impacts. The impacts of energy on the nature is a research area that has emerged from the 1980s [1]. The direct and indirect impacts of energy consumed include adverse problems like global climate change, stratospheric ozone depletion and acid rains [2]. Other impacts include health issues to the people and other living organisms [1], global warming, emission of radioactive substances, forest destruction [2], greenhouse gas (GHG) emission[3], and pollution of air, water and land. The by-products from the extraction, production, networking and consumption of energy define the largest single environmental loading of society when taken together [3].

This paper is an attempt to investigate the impact of energy as an urban form determinant (UFD) [4] in shaping the human settlements. The use of energy by human beings has changed from the time when the evolutionary predecessors of homo-sapiens were foragers in the Stone Age, to people of modern history. During Stone Age, the energy used by human beings was primarily for hunting and gathering. This accounted for about 2500 calories per day, and the average amount of calories consumed by one person living in USA (in 1968) was found to be 200,000 [5]. When human beings discovered different forms of resources from which they can extract energy; the lifestyle, the kinds of shelter, the food habits, the types and locations of settlements changed. They began to use energy for providing, building indoor comfort, transporting goods \& people, and for other activities. The average energy used in different ages of human history is shown in Fig. 1.

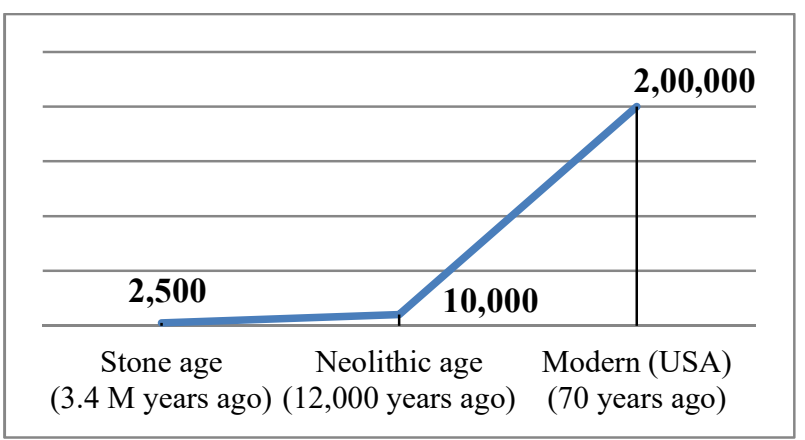

Fig. 1. Average energy used per day by human beings during different ages of history. [5] 


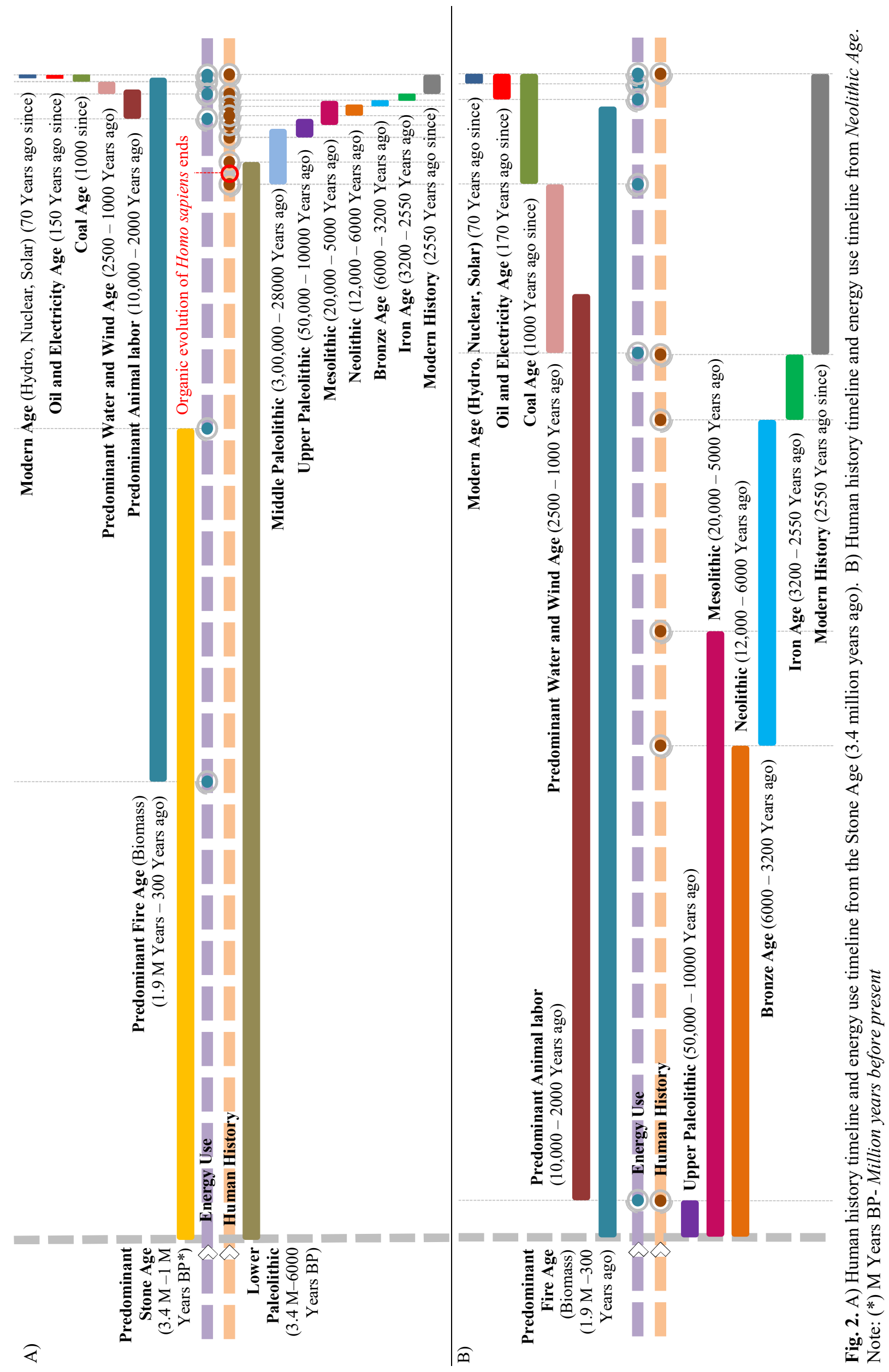


This can be better understood by comparing the human history with the history of energy used; which is shown in Fig. 2. The figure explains the beginning and ending of different human prehistoric ages along with a timeline of energy. Since the exact ending of all energy eras mentioned in the energy timeline will not be a specific year, the diagram shows the predominant energy used at a specific time period. It is clearly visible that the discovery of new types of energy forms has had a massive impact in the development of settlements. The discovery of new sources of energy meant that humans started extracting more energy and storing them, instead of using them at once.

The 'energy balance' as quoted by Smil [6], between energy extracted and used was at equilibrium at some point during the foragers era. This balance was lost in the human settlements that followed, which lead to unsustainable development, with humans consuming more resources than what is required for their survival. Between $1500 \mathrm{AD}$ to $2014 \mathrm{AD}$, the human population has increased 14-fold (500 million to 7 billion) and the energy use by humanity has increased 115-fold (13 trillion calories/day to 1500 trillion calories/day) [7].

The modern history (2550 years ago since) of human settlements have witnessed a great number of developments in the energy sector and the 'threats' mentioned above can be associated with these events.

To understand the changes in the human settlements in this timeline, one settlement from each of the energy eras in Fig. 2 were selected. Framework for assessing these settlements was selected from literature.

\section{Methodology \& analysis}

\subsection{Structure of the study}

Different frameworks have been used to study the evolution of human settlements, to understand its patterns and principles, the cultural base and socioeconomic infrastructure. The prominent ones among these include the one developed by Patrick Geddes based on key units of work, folk and place [8]; UFD framework by Morris [4], Central Place Theory by Walter Christaller [9], General Systems Theory by Ludwig von Bertalanffy [10], Regional Input-Output Analysis by Isard [11], Growth Centers and Human Settlements by Hansen [12], Business Organisation and Spatial Organisation by Lasuen [13]. The framework used for this study is the UFD framework by Morris, for the depth in analysis provided in the framework using sixteen UFDs (three natural and thirteen man-made), and one additional UFD (energy), which are listed in Table 1. Using these determinants will also enable a researcher to understand the interdependence of various determinants.

Table 1. UFDs used in the framework for the study.

\begin{tabular}{|l|l|l|}
\hline \multicolumn{2}{|l|}{ Natural determinants } & Code \\
\hline 1 & Topography & $\mathrm{N}_{1}$ \\
\hline 2 & Climate & $\mathrm{N}_{2}$ \\
\hline 3 & Materials and construction technology & $\mathrm{N}_{3}$ \\
\hline Man-made determinants & $\mathrm{M}_{1}$ \\
\hline 1 & Economic & \\
\hline
\end{tabular}

\begin{tabular}{|l|l|l|}
\hline 2 & Political & $\mathrm{M}_{2}$ \\
\hline 3 & Religious & $\mathrm{M}_{3}$ \\
\hline 4 & Pre-urban cadastre & $\mathrm{M}_{4}$ \\
\hline 5 & Defence & $\mathrm{M}_{5}$ \\
\hline 6 & Aggrandizement & $\mathrm{M}_{6}$ \\
\hline 7 & Grid-iron & $\mathrm{M}_{7}$ \\
\hline 8 & Urban mobility & $\mathrm{M}_{8}$ \\
\hline 9 & Aesthetic & $\mathrm{M}_{9}$ \\
\hline 10 & Legislation & $\mathrm{M}_{10}$ \\
\hline 11 & Urban infrastructure & $\mathrm{M}_{11}$ \\
\hline 12 & Social, religious and ethnic groups & $\mathrm{M}_{12}$ \\
\hline 13 & Leisure & $\mathrm{M}_{13}$ \\
\hline \multicolumn{2}{|l}{ Additional determinant considered } \\
\hline 1 & Energy & $\mathrm{E}_{1}$ \\
\hline
\end{tabular}

\subsection{Selection of settlements}

Permanent physical units for living did not exist before $14000 \mathrm{BC}$ and the first civilizations were established during the late stages of Bronze Age. The decisive step towards the formation of urban civilization was due to the end of the last of ice ages around $7000 \mathrm{BC}$, which made the environment, friendly for the humans, to exploit the organic world [4].

The settlements are selected as representative case studies which fall in the energy eras shown in Fig. 2. To understand the influence of energy in shaping the settlements, case studies are selected such that they had minimal external influences in their development; and they fall into similar climatic conditions and geographic regions. Since the earliest known human civilizations (Sumerian civilization) are from 5000 BC [4], settlements before $5000 \mathrm{BC}$ are not selected for the study. The settlements selected, and their characteristic features are shown in Table 2; and their layouts are shown in Fig. 4, Fig. 5 and Fig. 6. Table 2 explains the energy era and human history era to which the selected settlements belong to; the predominant energy source and the important elements of the settlements.

\subsection{Data presentation}

To understand the UFDs which influence the energy consumed in the case settlements, it is essential to know the various activities which consumed energy in a specific human era. The average per capita annual energy consumption for various activities over the history of humans stated by Smil [6] is shown in Fig. 3.

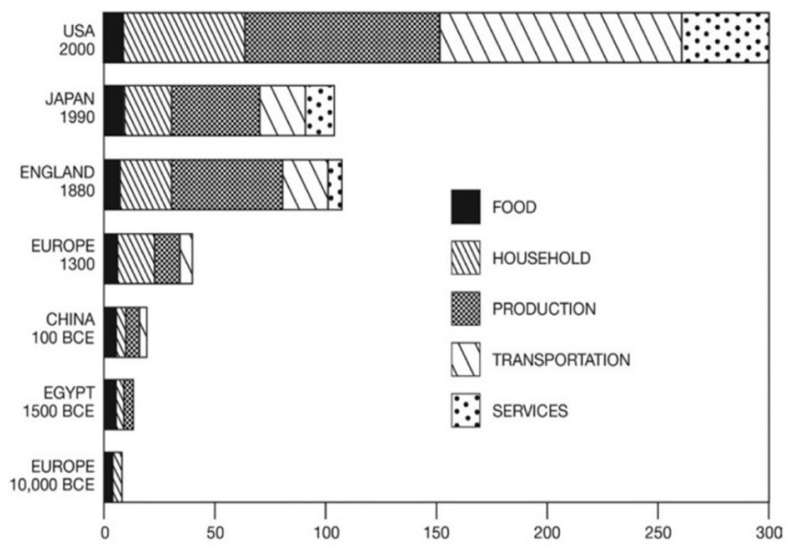

Fig. 3. Per capita energy consumption (GJ/year) (Source: [6]). 
Table 2. Settlements selected for the study and their characteristics.

\begin{tabular}{|c|c|c|c|c|c|c|c|c|}
\hline $\begin{array}{l}\dot{z} \\
\dot{\omega}\end{array}$ & Settlement & Reason for emergence & 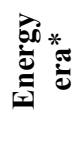 & 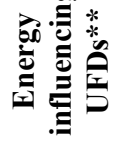 & $\begin{array}{l}\text { Predominant } \\
\text { energy source }\end{array}$ & $\begin{array}{c}\text { Human } \\
\text { history era }\end{array}$ & $\begin{array}{l}\text { Important elements } \\
\text { of settlement }\end{array}$ & Ref \\
\hline 1 & $\begin{array}{l}\text { 'Ur of the } \\
\text { Chaldees' }\end{array}$ & $\begin{array}{l}\text { Unplanned development } \\
\text { grown out of long } \\
\text { evolutionary process }\end{array}$ & $(b, c)$ & $\begin{array}{l}\left(\mathrm{N}_{1-2}\right. \\
\left.\mathrm{M}_{1,2,8}\right)\end{array}$ & $\begin{array}{l}\text { i.Human \& } \\
\text { animal labour } \\
\text { ii.Biomass } \\
\text { iii.Wind }\end{array}$ & $\begin{array}{l}\text { Neolithic: } \\
\text { Mesopotamia } \\
\text { n (Sumerian) }\end{array}$ & $\begin{array}{l}\text { i.North harbour } \\
\text { ii.West harbour } \\
\text { iii. 'Temanos' } \\
\text { iv.Housing district }\end{array}$ & {$[4]$} \\
\hline 2 & Athens & $\begin{array}{l}\text { Organic growth with } \\
\text { special attention to } \\
\text { spatial relationships and } \\
\text { layouts determined by } \\
\text { inherited constraints. }\end{array}$ & $(\mathrm{d}, \mathrm{b})$ & $\begin{array}{l}\left(\mathrm{N}_{1-3}\right. \\
\mathrm{M}_{1-3,6-} \\
9,13)\end{array}$ & $\begin{array}{l}\text { i.Human \& } \\
\text { animal labour } \\
\text { ii.Biomass } \\
\text { iii.Water \& wind }\end{array}$ & Bronze Age & $\begin{array}{l}\text { i.Acropolis } \\
\text { ii.Agora } \\
\text { iii.Pnyx } \\
\text { iv.Long walls } \\
\text { v.Olympieion temple }\end{array}$ & {$[4]$} \\
\hline 3 & Winchester & $\begin{array}{l}\text { Medieval town } \\
\text { influenced by the } \\
\text { original gridiron } \\
\text { structure of Roman } \\
\text { Venta Belgarum. } \\
\end{array}$ & $(\mathrm{d}, \mathrm{b})$ & $\begin{array}{l}\left(\mathrm{M}_{1-2,}\right. \\
4-7,9-10)\end{array}$ & $\begin{array}{l}\text { i.Human \& } \\
\text { animal labour } \\
\text { ii.Biomass } \\
\text { iii.Water \& wind }\end{array}$ & Medieval & $\begin{array}{l}\text { i.Castle } \\
\text { ii.Market place } \\
\text { iii.Street } \\
\text { iv.Defence wall } \\
\text { v.Square } \\
\end{array}$ & $\begin{array}{l}{[4,} \\
14]\end{array}$ \\
\hline 4 & Turin & $\begin{array}{l}\text { Roman colony in the } \\
15^{\text {th }} \text { century which was } \\
\text { extended during } \\
\text { Renaissance period. }\end{array}$ & $(\mathrm{e}, \mathrm{b})$ & $\begin{array}{l}\mathrm{N}_{3} \\
\mathrm{M}_{1-2,4-} \\
9,11-12)\end{array}$ & $\begin{array}{l}\text { i.Human \& } \\
\text { animal labour } \\
\text { ii.Biomass } \\
\text { iii.Water \& wind } \\
\text { iv.Coal }\end{array}$ & Renaissance & $\begin{array}{l}\text { i.Fortification } \\
\text { ii.Primary straight } \\
\text { street/stations } \\
\text { iii.Gridiron districts } \\
\text { iv.Enclosed spaces }\end{array}$ & {$[4]$} \\
\hline 5 & Paris & $\begin{array}{l}\text { Reorganization and } \\
\text { remodelling of the city } \\
\text { in } 1850 \mathrm{~s} \text {, which took } \\
\text { place after the industrial } \\
\text { revolution began. }\end{array}$ & (e) & $\begin{array}{l}\mathrm{N}_{2} \\
\mathrm{M}_{1-2,4-} \\
11,13)\end{array}$ & $\begin{array}{l}\text { i.Coal } \\
\text { ii.Human \& } \\
\text { animal labour } \\
\text { iii.Water \& wind }\end{array}$ & $\begin{array}{l}\text { Modern era- } \\
\text { Industrial } \\
\text { revolution }\end{array}$ & $\begin{array}{l}\text { i.Civic centres } \\
\text { ii.Traffic } \\
\text { iii.Gridiron } \\
\text { iv.Symmetry \& } \\
\quad \text { balance }\end{array}$ & {$[15]$} \\
\hline 6 & Vancouver & $\begin{array}{l}\text { Post-industrial city with } \\
\text { emphasis on offices, } \\
\text { middle-class residential } \\
\text { land-use, recreation, and } \\
\text { entertainment } \\
\text { facilities }\end{array}$ & $(\mathrm{f}, \mathrm{e})$ & $\begin{array}{l}\left(\mathrm{N}_{3},\right. \\
\mathrm{M}_{1-4,6-} \\
\left.{ }_{13}\right)\end{array}$ & $\begin{array}{l}\text { i.Fossil fuels } \\
\text { ii.Electricity } \\
\text { iii.Coal } \\
\text { iv.Human \& } \\
\quad \text { animal labour }\end{array}$ & $\begin{array}{l}\text { Modern era- } \\
\text { Post- } \\
\text { industrialism }\end{array}$ & $\begin{array}{l}\text { i.Gentrified } \\
\text { neighbourhoods } \\
\text { ii.Leisure, luxury \& } \\
\text { entertainment hubs } \\
\text { iii.Gridiron } \\
\text { iv.Slums outside city }\end{array}$ & $\begin{array}{l}{[16-} \\
17]\end{array}$ \\
\hline 7 & $\begin{array}{l}\text { Neighbourh } \\
\text { ood unit }\end{array}$ & $\begin{array}{l}\text { Revitalizing existing } \\
\text { neighbourhoods to } \\
\text { reduce urban expansion, } \\
\text { provide social equity, } \\
\text { and enhance } \\
\text { sustainability with smart } \\
\text { technologies. }\end{array}$ & $\begin{array}{l}\text { (f,g, } \\
\text { e) }\end{array}$ & $\begin{array}{l}\left(\mathrm{N}_{3},\right. \\
\mathrm{M}_{1-2,4} \\
8-13)\end{array}$ & $\begin{array}{l}\text { i.Electricity } \\
\text { ii.Fossil fuels } \\
\text { iii.Coal } \\
\text { iv.Renewable } \\
\text { energy } \\
\text { v.Solar powered } \\
\text { cities }\end{array}$ & $\begin{array}{l}\text { Post- } \\
\text { modernism }\end{array}$ & $\begin{array}{l}\text { i.Smart \& } \\
\text { sustainable } \\
\text { neighbourhoods } \\
\text { ii. Transit oriented } \\
\text { development } \\
\text { iii.Pedestrian } \\
\text { networks }\end{array}$ & $\begin{array}{l}{[17-} \\
18]\end{array}$ \\
\hline
\end{tabular}

Note:

(*)- Stone age (a), Fire age (b), Animal labour (c), Water \&wind age (d), Coal age (e), Oil \& electricity age (f), Modern age (g) $(* *)$ - Codes as shown in Table 1.

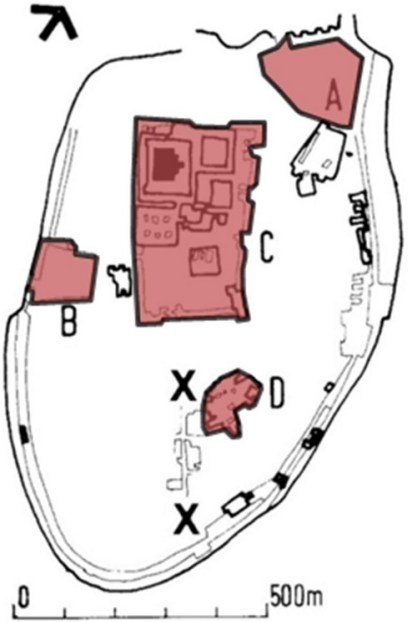

Fig. 4. Layouts and important elements of settlements selected for the study. 1) Ur of the Chaldees (left), 3) Winchester (right) (Source: [4])
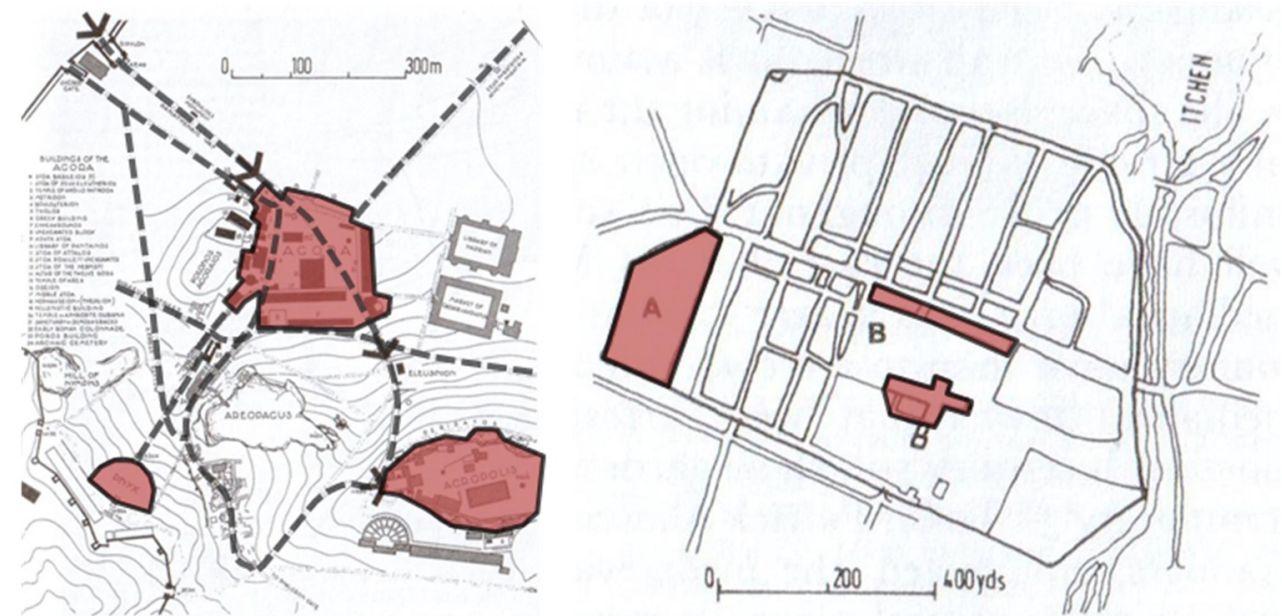

2) Athens (centre), 


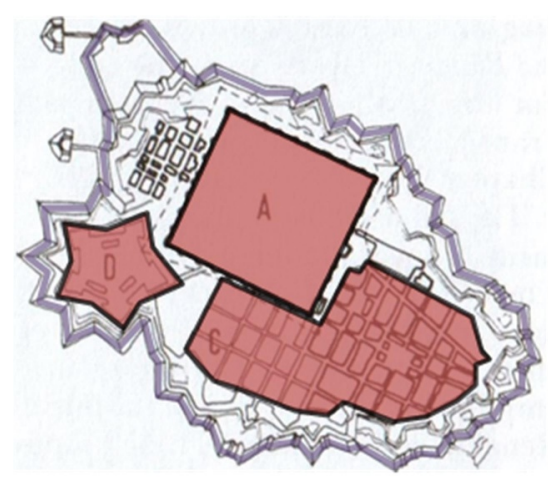

Fig. 5. 4) Turin (left),

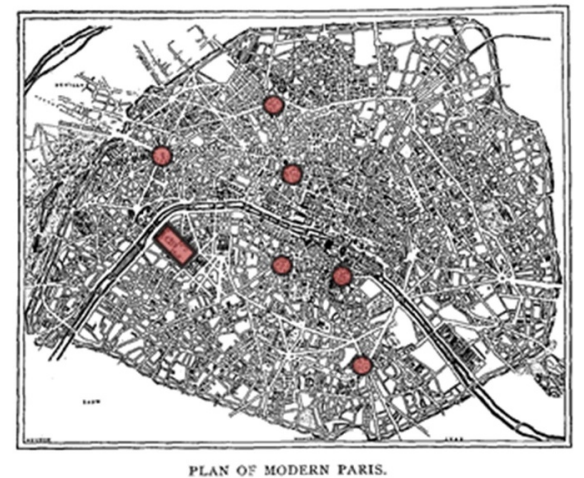

6) Vancouver (right) (Source: $[4,16,18])$

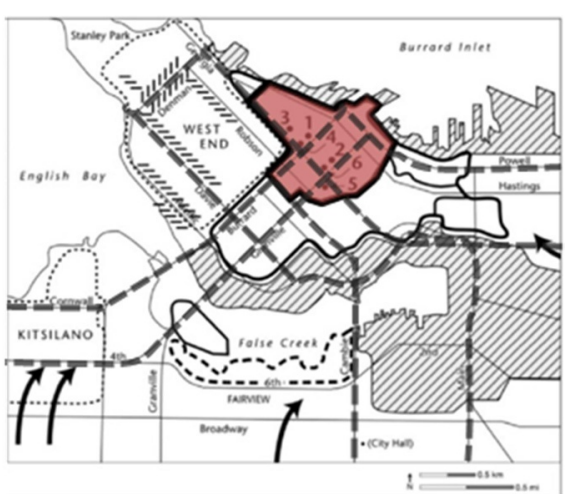

5) Paris (centre),

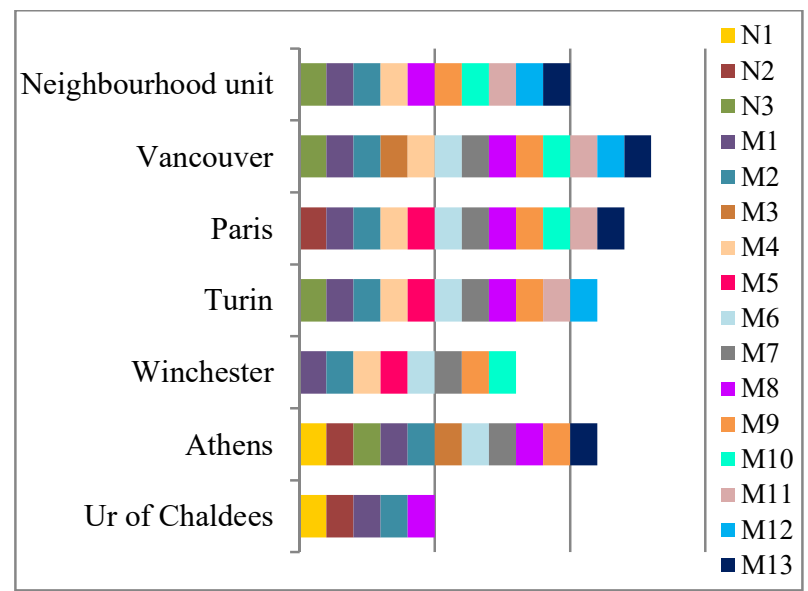

Fig. 7. UFDs influencing energy consumed in the selected settlements. (UFD codes as given in Table 1)

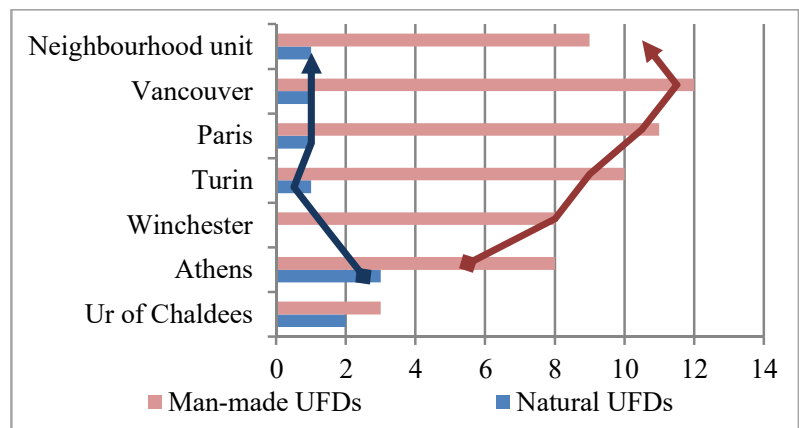

Fig. 8. Distribution of natural and man-made UFDs influencing energy consumed in the selected settlements.

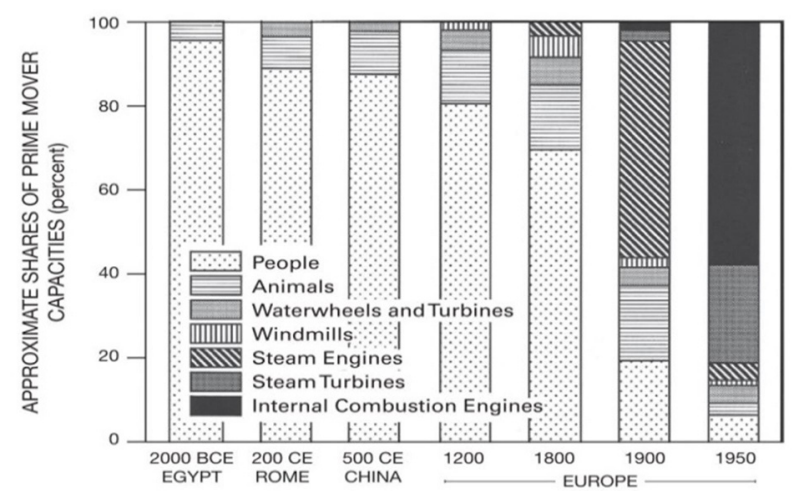

Fig. 9. Share of prime movers (in percentage)(Source: [6])

The earliest of human settlements (barbarism) were completely based on human muscular energy and the settlements thrived in areas located closer to the sources 
of energy, which ensured highest energy returns. The highest population density during the Palaeolithic Age were in coastal settlements, where hunting of much larger mammals was possible and the population density was ten times higher than forest settlements [20]. The assessment also indicates the use of more advanced energy sources in the prehistoric settlements. For instance, in $U r$, the existence of harbour and market places beside them indicates the use of wind energy for transportation of goods, even though the settlement belongs to the fire and animal labour energy era. Such overlaps exist depending on the materials and technology available with a specific settlement.

The development of methods of transmitting energy meant that settlements no longer needed to be located close to the source of energy, which led to settlements moving away from the coastal areas and river valleys, into the inlands. It is safe to say that the settlements that followed had one of its objectives to make this transmission of energy uncomplicated. This statement can be validated by the fact that five of the six case settlements, after humans started using energy source other than human labour and animal labour, were influenced by grid-iron and urban mobility, which will make this transmission unsophisticated. The peak of this change was during the industrial revolution and postindustrial period. The post-modern cities, which are trying to create low-carbon sustainable settlements, are planning layouts to exploit renewable energy sources. The influence of energy in shaping the settlements is evident from the study. It can be questioned if we can understand and learn from our early settlements better, when energy is included as one of the determinants in the frameworks used for assessing them.

\section{Conclusions}

Energy as a determinant had a major role in shaping the early settlements and is a major driving force which shapes the current settlements. The use of energy in human settlements has changed with time. When humans started relying progressively on man-made energy sources, they have inevitably started moving away from nature. This change is what triggered the unsustainable development patterns, as energy was no longer the deciding factor for the survival of human beings but was a driving force in changing their lifestyle from foragers, to farmers with permanent settlements, and to the cities of modern era.

Political \& economic UFDs had the most influence in energy consumption of past settlements, which shows that the settlements were not driven by energy efficiency awareness but social \& political awareness. To make the future development sustainable, we will have to gain insight from the earliest settlements, where energy was derived directly from the source, the energy returns were at equilibrium, and ensured minimal impact to the surrounding ecosystem. The future sustainable settlements will have to derive energy from direct sources like kinetic energy of the oceans, and heat from the sun rather than converting them to unsustainable forms [5]. It is the need of the hour that we question if compact cities are actually the solution to make the future development sustainable; to harness renewable energy from sunlight, heat, wind and rainwater; to employ the landscape of the city to purify our air, water and land; and to exploit the human resources for nature, against our past trends.

\section{References}

1. W. H. Qu, L. Xu, G. H. Qu, Z. J. Yan, and J. X. Wang, Nat. Hazards 87, 675 (2017)

2. I. Dincer, Energy Policy 27, 845 (1999)

3. S. Bilgen, Renew. Sustain. Energy Rev. 38, 890 (2014)

4. A. E. J. Morris, History of Urban Form before the Industrial Revolutions (Routledge, New York, 1972)

5. C. A. Doxiadis, Athens Cent. Ekistics 26, 455 (1968)

6. V. Smil, Energy and Civilisation- A History (2017)

7. Y. N. Harari, Sapiens: A Brief History of Humankind. (Random House, 2014)

8. P. Geddes, Cities in Evolution (London, 1949)

9. C. W. B. \& W. C. B.J.I. Berry, Econ. Geogr. 43, 275 (1967)

10. L. Von Bertalanffy, Gen. Syst. Theory Found. Dev. Appl. 296 (1973)

11. W. Isard, Rev. Econ. Stat. 33, 318 (1951)

12. N. Hansen, Reg. Sci. Assoc. 38, (1977)

13. J. R. Lasuen, Urban Stud. 6, (1969)

14. T. B. James and E. Roberts, Mediev. Archaeol. 44, 181 (2000)

15. R. Schermerhorn Jr, Brooklyn Eng. Club, Proc. 102 (1912)

16. T. A. Hutton, Urban Stud. 41, 1953 (2004)

17. A. Mair, Polit. Geogr. Q. 5, 351 (1986)

18. A. Kylili and P. A. Fokaides, Sustain. Cities Soc. 15, 86 (2015)

19. A. Sharifi, Sustain. Cities Soc. 20, 1 (2016)

20. V. Smil, Encycl. Energy 6, 549 (2004) 